\title{
Growth in children with 45,XO Turner's syndrome
}

\author{
C. G. D. BROOK, G. MÜRSET, M. ZACHMANN, and A. PRADER \\ From the Department of Paediatrics, University of Zurich, Kinderspital, Zurich, Switzerland
}

\begin{abstract}
Brook, C. G. D., Mürset, G., Zachmann, M., and Prader, A. (1974). Archives of Disease in Childhood, 49, 789. Growth in children with 45,XO Turner's syndrome. The growth records of 64 patients with 45,XO chromosome constitution have been analysed. The extremely short stature of adults with this condition $(142.5 \mathrm{~cm})$ appears to be due to intrauterine growth failure, to a gradual decline in height velocity in childhood, and to the absence of a pubertal growth spurt. Pubic hair appeared in $68 \%$ of patients but was delayed both in relation to chronological age and to bone age. The growth failure is presumably the result of a genetic abnormality in the bones of these patients.

Treatment with oestrogens caused development of secondary sex characteristics but did not appear to affect final stature. The age of the patient when treatment was administered was not of significance in affecting the final height of the patients. Despite the reduction in adult height, the correlation between the height of the patients with Turner's syndrome and their parents was maintained, a roughly constant amount of height being lost through the chromosomal abnormality. This suggests that the genes whose action underlies the variation in adult height among the normal population must be located for the most part on the autosomes.
\end{abstract}

The syndrome of sexual infantilism, webbed neck, and cubitus valgus associated with short stature in females was described by Turner (1938) and shown subsequently to be due to a missing $\mathrm{X}$ chromosome (Ford et al., 1959). Though several types of mosaicism and malformation in many different body systems have been reported, short stature in patients with Turner's syndrome is invariable. The object of the present paper is to analyse more fully than previous authors (Haddad and Wilkins, 1959; Lemli and Smith, 1963; Almquist, Lindsten, and Lindvall, 1963; Weill and Bernfeld, 1971; Rosenberg and Tell, 1972) the growth disorder of patients with pure $45, \mathrm{XO}$ chromosome constitution.

\section{Materials and methods}

Chromosome studies have been performed on cultures of peripheral blood lymphocytes from 95 patients with the stigmata of Turner's syndrome. The results are shown in Table I. The growth data from the 64 patients with the chromosome constitution 45, XO form the basis of this report; 49 of the patients were seen on two or more occasions at intervals of at least one year, and 15 were seen once only.

Heights were plotted on standard charts (Tanner,

Received 14 March 1974.
TABLE I

Chromosomal findings in 95 patients with Turner's syndrome

\begin{tabular}{l|c}
\hline & No. of patients \\
\hline $45, \mathrm{XO}$ & 64 \\
$45, \mathrm{XO} / 46, \mathrm{XX}$ & 10 \\
$46, \mathrm{XX} \mathrm{qi}_{\mathrm{qi}}$ & 4 \\
$45, \mathrm{XO} / 46, \mathrm{XX}_{\mathrm{qi}}$ & 7 \\
$45, \mathrm{XO} / 46, \mathrm{XX}_{\mathrm{r}}$ & 6 \\
$46, \mathrm{XX}$ & 3 \\
Other & 1 \\
\hline
\end{tabular}

Whitehouse, and Takaishi, 1966) and heights at annual intervals (at age $5 \cdot 0,6 \cdot 0$, etc.) taken from the straight lines connecting the points. Height velocities were calculated in individual cases from the differences between the yearly estimates.

Where appropriate the data were expressed and analysed as standard deviation scores (SDS) (Snedecor and Cochran, 1967) in order to allow for means and SDs which change with age and sex. These are calculated from the formula SDS $=\mathrm{X}-\overline{\mathrm{x}} / \mathrm{s}$, where $\mathrm{X}$ is the measurement of the individual, and $\bar{x}$ and $s$ the mean and SD in the normal population. The mean SDS in the normal population is 0 with SD of 1 . Thus, the SDS in an individual case represents the proportion of 1 SD by which the individual differs from the mean. By 
comparing the growth measurements to the normal means and SDs at the chronological age (CA) or bone age (BA), allowance could be made for the varying rates of maturation in the patient.

Birthweights were compared to the standards of Tanner and Thomson (1970), making allowance for gestational age and maternal height and parity. Birth lengths were compared to the standards of Hohenauer (1973). Ponderal indices (PI) at birth were calculated from the formula (Rohrer, 1908):

$$
P I=\frac{100 \times \text { weight in } \mathrm{g}}{\text { length }^{3} \text { in cm }},
$$

and the distribution of the indices compared with the standards of Lubchenko, Hansman, and Boyd (1966) for newborns.

Height and height velocity data were compared to the standards of Tanner et al. (1966) and bone age data to the female standards of Greulich and Pyle (1959). Bone age velocities were calculated by dividing the bone age increments by the chronological time interval elapsed. Thus, a bone age which advanced at an average rate for a population gave a bone age velocity of $1 \cdot 0$ years/year.

\section{Results}

Birth length and weight. The mean birth length was $47.6 \mathrm{~cm}$ (SD $2 \cdot 83$ ) in 36 cases (mean SDS -1.01 , SD 1.36 ) and the mean birthweight $2.81 \mathrm{~kg}(\mathrm{SD} 0.51)$ in 55 cases. When allowance was made for maternal height and parity and for length of gestation the mean birthweight SDS was $-1 \cdot 20$ (SD 1 19). Both scores are significantly below zero $(P<0.01)$. The scatter of the ponderal indices in the centiles did not differ significantly from normal ( $X^{2}=4 \cdot 95,5$ degrees of freedom, not significant). There was thus a marked failure of intrauterine growth in patients with $45, \mathrm{XO}$ constitution.

Growth in childhood. Fig. 1 shows a composite graph of all the longitudinal data including the patients who received treatment with oestrogens. Table II shows the number of subjects and height velocities at each age; the mean annual height velocities of the untreated cases are compared with the standard velocity curves in Fig. 2. There is a progressive fall in height velocity during childhood and no evidence of a pubertal height spurt. The mean height at 11 years of age in all the cases, both longitudinal (19) and cross sectional (2), was $123 \cdot 7 \mathrm{~cm}$ : from this figure were subtracted and added the mean velocities obtained annually from the longitudinal cases to get the mean height curve of patients with 45,XO chromosome constitution shown in Fig. 3 (technique described in Tanner and Gupta, 1968).

Bone age was consistently and increasingly retarded in the untreated patients so that by the age of 16 it was, on average, about 3.6 'years' behind

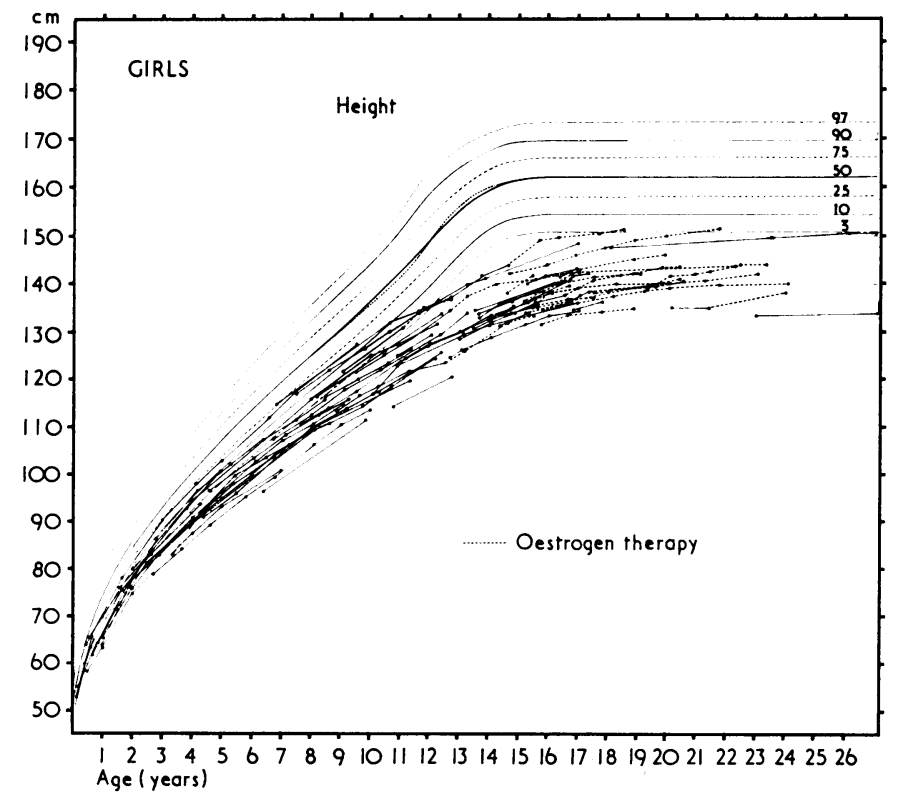

FIG. 1.-45,XO Turner's syndrome: linear growth in 49 patients. 
TABLE II

Height velocity in untreated patients with Turner's syndrome

\begin{tabular}{c|c|c|c}
\hline & & \multicolumn{2}{|c}{ Height velocity (cm/yr) } \\
\hline $\begin{array}{c}\text { Age } \\
\text { (yr) }\end{array}$ & $\begin{array}{c}\text { No. of } \\
\text { subjects }\end{array}$ & Mean & SD \\
\hline 0.5 & 9 & 19.9 & 3.05 \\
1.5 & 8 & 11.6 & 1.77 \\
2.5 & 10 & 7.6 & 1.29 \\
3.5 & 12 & 6.5 & 0.95 \\
4.5 & 11 & 5.7 & 1.00 \\
5.5 & 12 & 5.0 & 0.77 \\
6.5 & 12 & 4.8 & 0.83 \\
7.5 & 13 & 4.4 & 0.65 \\
8.5 & 14 & 4.0 & 0.71 \\
9.5 & 14 & 3.8 & 0.52 \\
10.5 & 15 & 3.9 & 0.60 \\
11.5 & 16 & 3.7 & 0.69 \\
12.5 & 11 & 3.3 & 0.83 \\
13.5 & 8 & 3.4 & 0.98 \\
14.5 & 11 & 2.3 & 0.70 \\
15.5 & 9 & 1.9 & 0.82 \\
& & & \\
\hline
\end{tabular}

*Age 3.5 indicates the year between ages 3.0 and 4.0 .

chronological age. The bone age SDS and bone age velocities are shown in Table III.

It is difficult to give a figure for final adult height in untreated patients with this condition, since reference to Fig. 1 indicates that extremely slow growth may continue well after age 20.4 patients had, however, reached an adult bone age without treatment and appeared to have stopped growing: their heights ranged from 131.5 to $150.5 \mathrm{~cm}$ (mean SDS -3.58). 14 patients had reached an adult bone age after treatment with oestrogens (see below) and their heights ranged from 134.8 to $152.0 \mathrm{~cm}$ (mean $143 \cdot 3 \mathrm{~cm}, \mathrm{SD} 4 \cdot 79$; mean SDS $-3 \cdot 12$, SD $0 \cdot 83)$.

In 17 of the patients who had stopped growing the heights of the parents were known. The mean midparental height (the arithmetic mean of the two heights of the parents) was $167.5 \mathrm{~cm}$ (SDS -0.25 compared to Zurich standards) and the mean height of the patients $142.5 \mathrm{~cm}$. The relation between the heights of the patients ( $y$ ) and the midparental heights $(x)$ is shown in Fig. 4. The regression equation was: $y=0 \cdot 64 x+35 \cdot 16$. The $S D$ of the regression coefficient was $0 \cdot 107$ and the correlation coefficient $0.84(P<0.001)$. The residual SD was 3.07 , which is $2 \cdot 15 \%$ of the mean value of the height of the children. Thus, the final height of patients with Turner's syndrome and 45,XO chromosome constitution could be predicted from

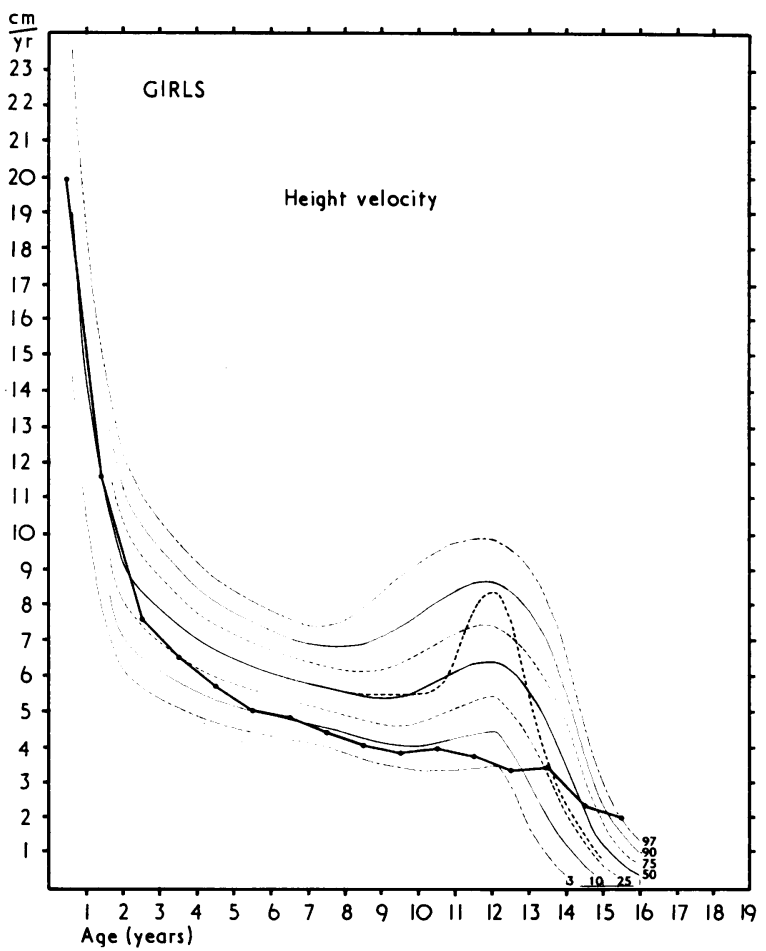

FIG. 2.-45,XO Turner's syndrome: mean yearly height velocities derived from data on 36 untreated patients. 


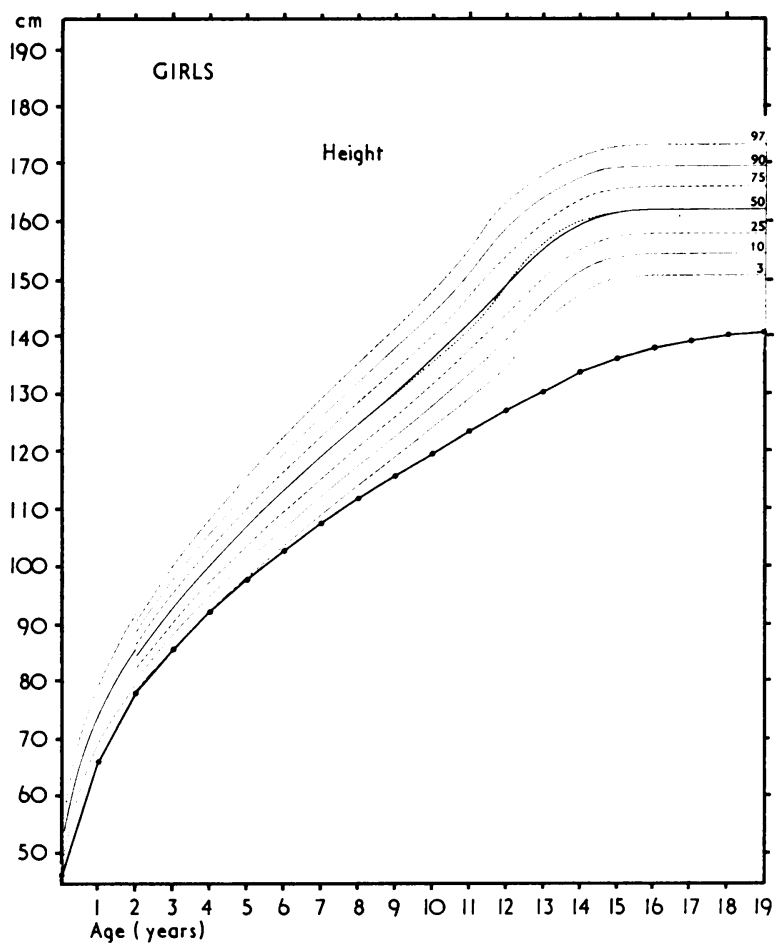

FIG. 3. -45,XO Turner's syndrome: mean height distance curve derived from mixed longitudinal data in 38 untreated patients.

the heights of their parents with an accuracy of $\pm 4.3 \%$ in $95 \%$ of cases.

A similar regression performed on 51 normal girls from the Zurich and London longitudinal growth studies gave the following regression equation: $y=0 \cdot 63 x+60 \cdot 35$. The regression coefficient is identical to that found in the patients with Turner's syndrome and the correlation coefficient in this case

TABLE III

Bone age and bone age velocity in untreated patients with Turner's syndrome

\begin{tabular}{|c|c|c|c|c|c|c|}
\hline \multirow{2}{*}{$\begin{array}{c}\mathrm{Age}^{\star} \\
(\mathbf{y r})\end{array}$} & \multicolumn{3}{|c|}{ Bone age SDS } & \multicolumn{3}{|c|}{ Bone age velocity (BA/CA) } \\
\hline & No. of subjects & Mean & SD & No. of subjects & Mean & SD \\
\hline $\begin{array}{r}1.5 \\
2.5 \\
3.5 \\
4.5 \\
5.5 \\
6.5 \\
7.5 \\
8.5 \\
9.5 \\
10.5 \\
11.5 \\
12.5 \\
13.5 \\
14.5 \\
15.5 \\
16.5\end{array}$ & $\begin{array}{r}5 \\
7 \\
7 \\
9 \\
7 \\
9 \\
9 \\
11 \\
10 \\
14 \\
13 \\
11 \\
10 \\
13 \\
12 \\
11\end{array}$ & $\begin{array}{l}-0.72 \\
-1.11 \\
-1.54 \\
-1.46 \\
-1.45 \\
-1.32 \\
-1.22 \\
-1.08 \\
-1.16 \\
-1.02 \\
-1.26 \\
-1.62 \\
-1.61 \\
-2.37 \\
-2.53 \\
-3.65\end{array}$ & $\begin{array}{l}1.30 \\
1.43 \\
1.28 \\
1.12 \\
1.01 \\
0.77 \\
0.79 \\
0.88 \\
0.55 \\
0.76 \\
0.86 \\
0.89 \\
0.69 \\
1.11 \\
0.84 \\
0.79\end{array}$ & $\begin{array}{r}7 \\
9 \\
8 \\
8 \\
8 \\
9 \\
10 \\
12 \\
11 \\
14 \\
11 \\
23 \\
14 \\
5 \\
3\end{array}$ & $\begin{array}{l}0.78 \\
0.69 \\
0.78 \\
0.91 \\
0.96 \\
0.99 \\
0.95 \\
0.99 \\
0.87 \\
0.85 \\
0.83 \\
0.78 \\
0.61 \\
0.82 \\
0.97\end{array}$ & $\begin{array}{l}0 \cdot 17 \\
0 \cdot 19 \\
0 \cdot 17 \\
0 \cdot 15 \\
0 \cdot 12 \\
0 \cdot 20 \\
0 \cdot 21 \\
0 \cdot 24 \\
0 \cdot 32 \\
0 \cdot 30 \\
0 \cdot 22 \\
0 \cdot 12 \\
0 \cdot 23 \\
0 \cdot 13 \\
0.09\end{array}$ \\
\hline
\end{tabular}

${ }^{\star}$ Age 3.5 indicates the year between ages $3 \cdot 0$ and $4 \cdot 0$. SDS, standard deviation score. 


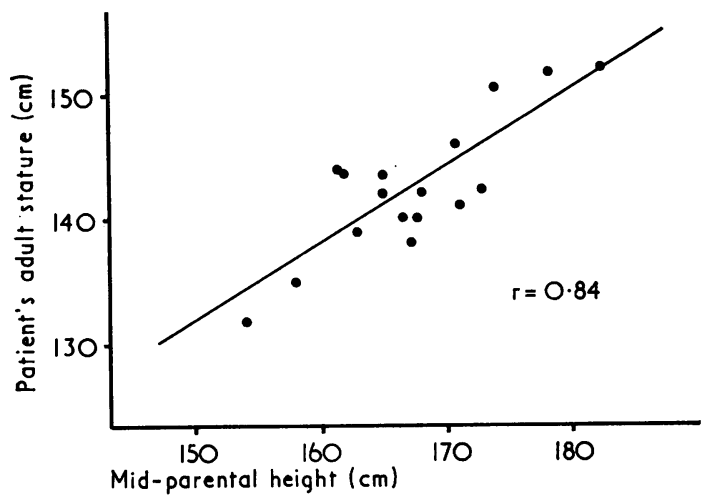

Fig. 4.-Correlation of adult stature of 17 patients with Turner's syndrome with midparental height.

was $0.60(P<0.001)$. The accuracy of the prediction was $\pm 4.9 \%$ in $95 \%$ of cases.

Pubertal changes. 35 patients were of a chronological and bone age when puberty might have been expected under normal circumstances. One patient underwent an entirely normal puberty with onset of menstruation at a bone age of 13 years; the blood chromosomes are not in doubt in this patient but other tissues were not cultured. The data from this patient were not included in the analyses. One other patient, seen only once, had apparently normal and spontaneous breast development, but the remainder did not.

Fig. 5 shows the chronological and bone ages at which pubic hair appeared in untreated patients compared to the chronological age at which it

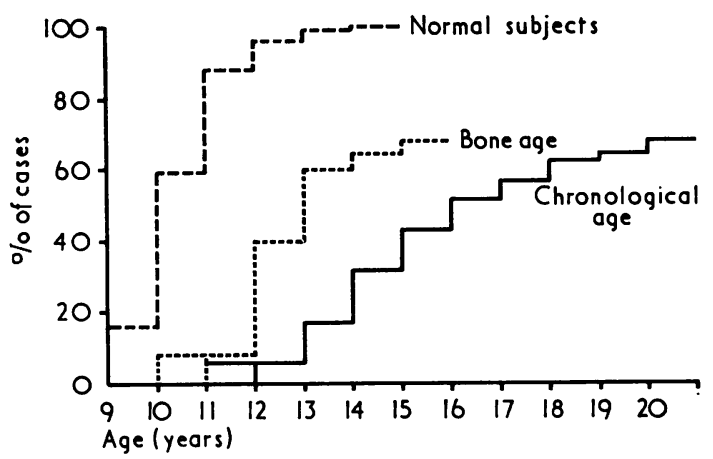

Fig. 5.-Appearance of pubic hair stage 2 in 137 normal subjects and 35 patients with Turner's syndrome.

appeared in 137 normal Zurich girls. Bone ages were not available for the controls, but in the patients the appearance of pubic hair was delayed not only with respect to chronological age but also to bone age. The distribution of pubic hair in the patients was normal but the amount greatly reduced. The spontaneous appearance of axillary hair was noted in a few patients. The velocity data were examined to see whether a height spurt occurred in patients in whom pubic hair appeared. The results are shown in Table IV. None of the differences between the groups reached statistical significance at the $5 \%$ level.

Effects of oestrogens. A variety of preparations was administered to 18 patients. Reference to Fig. 1 suggests that treatment, though causing a short spurt in growth in some patients, especially the

TABLE IV

Effect of appearance of pubic hair on height velocity in untreated patients with Turner's syndrome

\begin{tabular}{|c|c|c|c|c|c|c|}
\hline \multirow{3}{*}{$\underset{(\mathrm{yr})}{\mathrm{Age}^{\star}}$} & \multicolumn{6}{|c|}{ Height velocity $(\mathrm{cm} / \mathrm{yr})$} \\
\hline & \multicolumn{3}{|c|}{ With pubic hair } & \multicolumn{3}{|c|}{ Without pubic hair } \\
\hline & $\begin{array}{l}\text { No. of } \\
\text { subjects }\end{array}$ & Mean & SD & $\begin{array}{l}\text { No. of } \\
\text { subjects }\end{array}$ & Mean & SD \\
\hline $\begin{array}{l}\text { Chronological age } \\
10 \cdot 5 \\
11.5 \\
12.5 \\
13 \cdot 5 \\
14.5 \\
15.5\end{array}$ & $\begin{array}{l}4 \\
6 \\
6 \\
6 \\
8 \\
5\end{array}$ & $\begin{array}{l}4 \cdot 3 \\
3 \cdot 6 \\
3 \cdot 2 \\
3 \cdot 6 \\
2 \cdot 6 \\
2 \cdot 4\end{array}$ & $\begin{array}{l}0.22 \\
0.49 \\
0.90 \\
0.60 \\
0.68 \\
0.42\end{array}$ & $\begin{array}{l}5 \\
5 \\
4 \\
2 \\
3 \\
4\end{array}$ & $\begin{array}{l}3 \cdot 9 \\
3 \cdot 7 \\
3 \cdot 5 \\
3 \cdot 0 \\
1 \cdot 7 \\
1 \cdot 4\end{array}$ & $\begin{array}{l}0.79 \\
1.05 \\
1.02 \\
-7 \\
0.20 \\
0.90\end{array}$ \\
\hline $\begin{array}{c}\text { Bone age } \\
11.5 \\
12.5\end{array}$ & $\begin{array}{l}3 \\
6\end{array}$ & $\begin{array}{l}3 \cdot 2 \\
2 \cdot 6\end{array}$ & & $\begin{array}{l}3 \\
3\end{array}$ & $\begin{array}{l}3 \cdot 3 \\
2 \cdot 8\end{array}$ & \\
\hline
\end{tabular}

*Age 11.5 indicates the year between ages 11.0 and $12 \cdot 0$. 
younger ones, did not materially affect ultimate stature. It was not possible to analyse the velocity induced by treatment because there were insufficient untreated patients with whom to compare data; data from normal controls (standard data) are distorted by the effects of puberty. As far as bone age was concerned (Table V) oestrogen treatment advanced bone age with chronological age. This was only significantly greater than controls at age 13. Comparison of height for bone age SDS in individual subjects before and after 1 to 9 (mean 3.84 ) years of treatment showed a mean fall of 0.56 SDs (SD 0.53, P <0.001). This seems to imply a loss of $3.36 \mathrm{~cm}$ on final height, but two untreated patients fell respectively 0.40 and 0.62 SDs over a similar period, which suggests that these figures may be the result of extremely slow growth in late teens rather than an effect of treatment. There was no indication that the age at which oestrogens were administered had any effect on the growth result of treatment $\left(X^{2}=13 \cdot 52,15\right.$ d.f., not significant).

Effects of mosaicism. There were insufficient data to analyse properly the growth of these patients. Inspection did not reveal striking discrepancies from the pattern of growth of the pure cases. The final heights of $145 \cdot 3$ and $146 \cdot 1 \mathrm{~cm}$ in the $\mathrm{XO} / \mathrm{XX}$ and $\mathrm{XO} / \mathrm{XX}_{\mathrm{qi}}$ groups (height SDS $-2 \cdot 81$, SD $0 \cdot 87,9$ cases; and $-2 \cdot 68$, SD $0 \cdot 36,4$ cases) did not differ significantly either from each other or from those of the pure $\mathrm{XO}$ cases.

\section{Discussion}

These data show clearly that patients with Turner's syndrome are small from birth. It is worth stressing that the height velocity of these patients in childhood is strictly within normal limits (10th-25th centile), but a child who grows progressively smaller with respect to its peers. Bone age velocity was not as greatly reduced as linear growth, which resulted in a progressive fall in height for bone age which became further propersistently at this level does, of course, become

nounced when the pubertal growth spurt failed to make its contribution.

What causes this spurt in normal girls is not known but it has been attributed, at least in part, to secretion of adrenal androgens. We assume that the appearance of pubic hair in the majority of our patients was an expression of adrenal androgen secretion. The fact that it was usually in a normal distribution, though rather sparse, may indicate a less-than-normal amount of androgen, but the patients who developed pubic hair did not show an increase in growth rate. This may have been due to insufficient androgen stimulation, or to a failure of the growth process to respond to androgens. The former is probably more likely, since oxandrolone has been reported as being effective in producing acceleration in height in patients with Turner's syndrome (Rosenbloom and Frias, 1973).

The effect of oestrogens, which were given to our patients in doses sufficient to induce the development of breasts and pubic and axillary hair, was to induce a short growth spurt in some children, particularly the younger ones. Treatment did not, however, appear to affect materially ultimate stature in comparison to untreated patients. This was a difficult point to analyse since it is clear that extremely slow growth continues in these patients for many years. There was, however, no evidence that the time of administration of oestrogen affected ultimate stature, which has obvious therapeutic implications.

The progressive growth failure in patients with Turner's syndrome is presumably an increasing manifestation of the main abnormality in this syndrome, which is most likely located in the bones. The abnormally coarse trabecular structure of the bones of these patients on $x$-ray examination is well known and was noted in our patients from an early age. It must be postulated that this abnormality and the growth failure have their origin in the missing chromosomal material.

This does not seem, however, to affect the heritability of stature. In normal subjects the correlations of a child's stature with his own adult

TABLE V

Effect of oestrogen therapy on bone age in patients with Turner's syndrome

\begin{tabular}{|c|c|c|c|c|c|c|c|c|}
\hline \multirow{2}{*}{$\begin{array}{l}\text { Age } \\
(\mathbf{y r})\end{array}$} & \multicolumn{3}{|c|}{ Bone age velocity in untreated patients } & \multicolumn{3}{|c|}{ Bone age velocity in treated patients } & \multirow{2}{*}{ t } & \multirow{2}{*}{$\mathbf{P}$} \\
\hline & $\begin{array}{l}\text { No. of } \\
\text { subjects }\end{array}$ & Mean & SD & $\begin{array}{l}\text { No. of } \\
\text { subjects }\end{array}$ & Mean & SD & & \\
\hline $\begin{array}{l}13 \cdot 5 \\
14 \cdot 5 \\
15 \cdot 5\end{array}$ & $\begin{array}{r}14 \\
5 \\
3\end{array}$ & $\begin{array}{l}0 \cdot 61 \\
0 \cdot 82 \\
0 \cdot 97\end{array}$ & $\begin{array}{l}0 \cdot 23 \\
0 \cdot 13 \\
0 \cdot 09\end{array}$ & $\begin{array}{l}8 \\
7 \\
8\end{array}$ & $\begin{array}{l}1 \cdot 19 \\
1 \cdot 04 \\
1 \cdot 15\end{array}$ & $\begin{array}{l}0 \cdot 31 \\
0 \cdot 35 \\
0 \cdot 27\end{array}$ & $\begin{array}{l}5 \cdot 26 \\
1 \cdot 45 \\
1 \cdot 21\end{array}$ & $\begin{array}{l}<0.001 \\
\text { NS } \\
\text { NS }\end{array}$ \\
\hline
\end{tabular}


stature and with that of his parents change during growth (Tanner, 1962), which is presumably due, at least partly, to different genes influencing the growth process at different times. Like Lemli and Smith (1963), we found a highly significant relation between the height of our patients and that of their parents. The slope of the regression was identical in the patients compared to normal subjects, which suggests that a fairly uniform proportion of height is lost through the absence of one $\mathrm{X}$ chromosome. It implies that the genes whose action underlies the variation in adult height among the normal population must be located for the most part on autosomes.

We are grateful to Professor Dr. med. W. Schmid for performing the chromosome analyses on our patients and to Professor J. M. Tanner for his helpful criticism of the manuscript. C.G.D.B. gratefully acknowledges the financial assistance of the Wellcome Trust.

\section{REFBRENCES}

Almquist, S., Lindsten, J., and Lindvall, N. (1963). Linear growth, sulphation factor activity and chromosome constitution in 22 subjects with Turner's syndrome. Acta Endocrinologica, 42, 168.

Ford, C. E., Jones, K. W., Polani, P. E., De Almeida, J. C., and Briggs, J. H. (1959). A sex-chromosome anomaly in a case of gonadal dysgenesis. Lancet, 1, 711.

Greulich, W. W., and Pyle, S. I. (1959). Radiographic Atlas of Skeletal Development of the Hand and Wrist, 2nd ed. Stanford University Press, California.

Haddad, H. M., and Wilkins, L. (1959). Congenital anomalies associated with gonadal aplasia. Pediatrics, 23, 885.
Hohenauer, L. (1973). Intrauterines Längen und Gewichtswachstum. Pädiatrie und Pädologie, 8, 195.

Lemli, L., and Smith, D. W. (1963). The XO syndrome: a study of the differentiated phenotype in 25 patients. Fournal of Pediatrics, 63, 577.

Lubchenko, L. O., Hansman, C., and Boyd, E. (1966). Intrauterine growth in length and head circumference as estimated from live births at gestational ages from 26 to 42 weeks. Pediatrics, 37, 403.

Rohrer, F. (1908). Eine neue Formel zur Bestimmung der Körperfülle. Korrespondenz-blatt der Deutschen Gesellschaft für Anthropologie, 39, 5.

Rosenberg, D., and Tell, G. (1972). Syndrome de Turner. A propos d'une statistique de 60 observations. Pédiatrie, 27, 831 .

Rosenbloom, A. L., and Frias, J. L. (1973). Oxandrolone for growth promotion in Turner syndrome. American fournal of Diseases of Children, 125, 385.

Snedecor, G. W., and Cochran, W. G. (1967). Statistical Methods, 6th ed., p. 35. Iowa State University Press, Ames, Iowa.

Tanner, J. M. (1962). Growth at Adolescence, 2nd ed., p. 118. Blackwell, Oxford.

Tanner, J. M., and Gupta, D. (1968). A longitudinal study of the urinary excretion of individual steroids in children from 8 to 12 years old. Fournal of Endocrinology, 41, 139.

Tanner, J. M., and Thomson, A. M. (1970). Standards for birthweight at gestation periods from 32-42 weeks, allowing for maternal height and weight. Archives of Disease in Childhood, $45,566$.

Tanner, J. M., Whitehouse, R. H., and Takaishi, M. (1966). Standards from birth to maturity for height, weight, height velocity, and weight velocity. British children, 1965. Archives of Disease in Childhood, 41, 454, 613.

Turner, H. H. (1938). A syndrome of infantilism, congenital webbed neck, and cubitus valgus. Endocrinology, 23, 566.

Weill, J., and Bernfeld, J. (1971). Le trouble de la croissance dans le syndrome de Turner. Revue Franfaise d'Endocrinologie Clinique, 12, 483.

Correspondence to Dr. C. G. D. Brook, The Middlesex Hospital, London W1N 8AA. 